\title{
Numerical Simulations of Carrier-selective Contact Silicon Solar Cells: Role of Surface Passivation and Carrier-Selective Layers Electronic Properties
}

\section{KRISHNA SINGH}

IIT Delhi: Indian Institute of Technology Delhi https://orcid.org/0000-0002-4656-283X

\section{Dipak Kumar Singh}

NIT Patna: National Institute of Technology Patna

Vamsi K. Komarala ( $\sim$ vamsi@ces.iitd.ac.in )

IIT Delhi: Indian Institute of Technology Delhi

\section{Research Article}

Keywords: Carrier-selective, Electronic Properties, lithium fluoride

Posted Date: May 13th, 2021

DOI: https://doi.org/10.21203/rs.3.rs-491788/v1

License: (c) (i) This work is licensed under a Creative Commons Attribution 4.0 International License.

Read Full License

Version of Record: A version of this preprint was published at Journal of Computational Electronics on August 4th, 2021. See the published version at https://doi.org/10.1007/s10825-021-01750-3. 


\section{Abstract}

$\mathrm{Ag} / \mathrm{ITO} / \mathrm{MoO}_{\mathrm{x}} / \mathrm{n}-\mathrm{Si} / \mathrm{LiF}_{\mathrm{x}} / \mathrm{Al}$ carrier-selective contact (CSC) solar cell structures are modelled and numerically simulated based on the experimental data using an industrial quality base silicon wafer by the Sentaurus TCAD software. The role of (1) electron-selective lithium fluoride $\left(\mathrm{LiF}_{\mathrm{x}}\right)$ layer and its thickness, (2) hole-selective molybdenum oxide $\left(\mathrm{MoO}_{\mathrm{x}}\right)$ work function variation, and (3) front contact $\left(\mathrm{MoO}_{\mathrm{x}} / \mathrm{n}\right.$-Si) surface passivation interlayer are explored on the device performance. The electron-selective $\mathrm{LiF}_{\mathrm{x}}$ layer at the rear side is led to the strong enhancement in device photocurrent by providing the electrical barrier to the minority carriers (holes) and slight improvement in open-circuit voltage, but the thickness of the layer is sensitive to efficient extraction of the majority carriers (electrons). The holeselective $\mathrm{MoO}_{\mathrm{x}}$ layer work function needs to engineer for inducing the strong inversion layer with better built-in potential at the $\mathrm{MoO}_{\mathrm{x}} / \mathrm{n}$-Si junction to achieve high open-circuit voltage from a cell. A thin $\mathrm{SiO}_{\mathrm{x}}$ interlayer at the $\mathrm{MoO}_{x} / \mathrm{n}$-Si junction has enhanced the device open-circuit voltage significantly by minimizing the minority carrier recombination at the interface.

\section{Introduction}

Carrier-selective contact (CSC) silicon solar cells are presently getting attension as an alternative to conventional silicon heterojunction (SHJ) cells due to simple fabrication, low parasitic absorption from carrier-selective layers, and high-efficiency potential [1-4]. CSC solar cells rely on wide-bandgap transition metal oxides (TMOs) for charge carrier extraction, where high work function (WF) materials such as molybdenum oxide $\left(\mathrm{MoO}_{\mathrm{x}}\right)$, vanadium oxide $\left(\mathrm{V}_{2} \mathrm{O}_{\mathrm{x}}\right)$ and tungsten oxide $\left(\mathrm{WO}_{\mathrm{x}}\right)$ are employed as holeselective layers [3,5], and low WF materials such as lithium fluoride $\left(\mathrm{LiF}_{\mathrm{x}}\right)$, magnesium fluoride $\left(\mathrm{MgF}_{\mathrm{x}}\right)$, and titanium oxide $\left(\mathrm{TiO}_{\mathrm{x}}\right)$ are used as electrons-selective layers [6-8]. The carrier selectivity in CSC cells happens through asymmetric energy band alignment of different TMOs with the c-Si; the difference in WF between TMOs and c-Si produces both extraction of charge carriers and field-effect surface passivation $[9,10]$.

Apart from experimental effort, the modelling and simulation study has been carried out on CSC solar cells to visualize the role of interface and bulk defect states on carrier recombination and transport mechanisms (band to band or trap-assisted tunnelling) $[9,11,12]$. However, a few research reports on the role of back (electron-selective) contact of CSC cells, Vijayan et al. [10] have observed an improvement in surface passivation and electron selectivity from $\mathrm{TiO}_{\mathrm{x}}$ layer along with $\mathrm{LiF}_{\mathrm{x}} / \mathrm{Al}$ stack by using Sentaurus device simulator. $\mathrm{LiF}_{\mathrm{x}}$ alone has also been used as an electron-selective layer due to its simple fabrication process to produce a low resistive path to electrons collection at the rear side of the CSC cell as $\mathrm{LiF}_{\mathrm{X}} / \mathrm{Al}$ stack [6]. Usually, a thin intrinsic amorphous silicon (i-a-Si:H) layers is used as an interface passivation layer on both conventional and CSC based SHJ cells. However, a thin $\mathrm{SiO}_{\mathrm{x}}$ interlayer can also be used as an alternative passivation layer $[13,14]$. 
In this work, we have investigated the CSC cells performance having the device structure $\mathrm{Ag} / \mathrm{ITO} / \mathrm{MoO}_{\mathrm{x}} / \mathrm{n}$ $\mathrm{Si} / \mathrm{LiF}_{\mathrm{X}} / \mathrm{Al}$ using the Sentaurus TCAD simulation, with the emphasis on the role of $\mathrm{LiF}_{\mathrm{x}}$ layer and its thickness in the electron selective back contact $\left(\mathrm{n}-\mathrm{Si} / \mathrm{LiF}_{\mathrm{x}} / \mathrm{Al}\right), \mathrm{MoO}_{\mathrm{x}}$ work function in the hole-selective contact $\left(\mathrm{MoO}_{\mathrm{x}} / \mathrm{n}-\mathrm{Si}\right)$, and the $\mathrm{SiO}_{\mathrm{x}}$ layer on chemical passivation at the front contact. The simulated energy band diagrams at both the contacts are considered for explaining the carrier transport barrier at the interfaces, and the light $\mathrm{J}-\mathrm{V}$ graphs in device performance. The numerical simulation parameters are considered based on our earlier reported experimental observations [15], to validate the simulated energy band diagrams and light $\mathrm{J}-\mathrm{V}$ graphs.

\section{Simulation Details}

The numerical solutions of Poisson, drift-diffusion, and carrier continuity equations are solved in a selfconsistent approach. Various physical models have been invoked to analyse the terminal characteristics of CSC solar cell accurately using Sentaurus TCAD software [16]. The thermionic emission model is employed at heterojunction interfaces, which defines the thermionic current and thermionic energy flux better at these abrupt junctions. The recombination of carriers is modelled by Shockley-Read-Hall (SRH) model that includes recombination through defects levels within the bandgap. The surface recombination velocity model is used at the c-Si surface to explore the effect of chemical passivation in the solar cell. The constant mobility model is used in c-Si as the concentration of carriers is low. In addition to these models, the tunnelling models have also been used to define the tunnelling at heterointerface as well as at thin insulator (such as $\mathrm{SiO}_{\mathrm{x}}$ and $\mathrm{LiF}_{\mathrm{x}}$ ). Here, the robust non-local tunnelling model based on the Wentzel-Kramers-Brillouin (WKB) tunnelling probability is used.

The optical generation model based on the complex refractive index of materials is taken to compute the generation from the input spectrum of wavelength. Here, we have employed the standard AM1.5 global as input spectrum to calculate the $\mathrm{J}-\mathrm{V}$ curve under the illumination. The transfer matrix method (TMM) has been used as an optical solver to calculate plain waves' propagation through layer media (materials). The complex refractive indices ( $n$ and $k$ ) of materials have been obtained from the Sentaurus database as well as from PV Lighthouse [17]. The schematic and energy band diagram of simulated CSC solar cell is shown in Figs. 1a and 1b, respectively. The material parameters used for the device simulation are tabulated in Table 1. 
Table 1

Material parameters considered in numerical simulation of CSC solar cells.

\begin{tabular}{|c|c|c|c|c|c|c|c|}
\hline Parameters & $\mathrm{Ag}$ & ITO & $\mathrm{MoO}_{\mathrm{x}}$ & $\mathrm{SiO}_{\mathrm{x}}$ & c-Si(n) & $\operatorname{LiF}_{x}$ & Al \\
\hline $\begin{array}{l}\text { Material } \\
\text { Assumption }\end{array}$ & Metal & Metal & Metal & Insulator & Semiconductor & Insulator & Meta \\
\hline Global model & - & \multicolumn{6}{|c|}{ Fermi, Thermionic emission, Hetero Interface, Drift-diffusion } \\
\hline Model Used & - & - & - & $\begin{array}{l}\text { Barrier } \\
\text { Tunnelling }\end{array}$ & - & $\begin{array}{l}\text { Barrier } \\
\text { Tunnelling }\end{array}$ & - \\
\hline Bandgap & - & - & - & $8.9 \mathrm{eV}$ & $1.12 \mathrm{eV}$ & $10 \mathrm{eV}$ & - \\
\hline Electron affınity & - & - & - & $1.0 \mathrm{eV}$ & $4.05 \mathrm{eV}$ & $2.87 \mathrm{eV}$ & - \\
\hline Work function & $\begin{array}{l}5.1 \\
\mathrm{eV}\end{array}$ & $\begin{array}{l}5.5 \\
\mathrm{eV}\end{array}$ & $\begin{array}{l}4.8- \\
6.7 \mathrm{eV}\end{array}$ & - & - & - & $\begin{array}{l}4.1 \\
\mathrm{eV}\end{array}$ \\
\hline Bulk lifetime & - & - & - & - & $300-2000 \mu s$ & - & - \\
\hline $\begin{array}{l}\text { Dielectric } \\
\text { constant }\end{array}$ & - & - & - & 3.9 & 11.7 & 6.0 & - \\
\hline $\begin{array}{l}\text { Electron } \\
\text { mobility }\end{array}$ & - & - & - & - & 1417 & - & - \\
\hline Hole Mobility & - & - & - & - & 470.5 & - & - \\
\hline $\begin{array}{l}\text { Tunnelling } \\
\text { mass }\left(\mathrm{m}_{\mathrm{t}} / \mathrm{m}_{\mathrm{e}}\right)\end{array}$ & - & - & - & 0.4 & - & 0.4 & - \\
\hline Doping Density & - & - & - & - & $3 \times 10^{15}$ & - & - \\
\hline
\end{tabular}

\section{Results And Discussion}

\subsection{Role of electron selective contact on cell performance:}

Figures $2 \mathrm{a}$ and $2 \mathrm{~b}$ show the light $\mathrm{J}-\mathrm{V}$ graphs and energy band diagrams of CSC cells with and without $\mathrm{LiF}_{\mathrm{x}}$ interlayer at the electron-selective back contact. The cell with $\mathrm{LiF}_{\mathrm{x}}$ structure shows an increase in efficiency by $\sim 2 \%$ due to an improvement in $\mathrm{V}_{\text {oc }}$ and $\mathrm{J}_{\mathrm{sc}}$ by $\sim 20 \mathrm{mV}$ and $\sim 3 \mathrm{~mA} / \mathrm{cm}^{2}$, respectively. The characteristics of both the J-V graphs are the same (Fig. 2a); however, the cell with $\mathrm{LiF}_{\mathrm{X}}$ (Fig. 2b) shows a downward bending in conduction and valance bands along with the better quasi fermi-level splitting.

The $\mathrm{LiF}_{\mathrm{x}}$ layer facilitates the downward band-bending at CSC cell's rear contact between the c-Si and Al, due to the low WF. The band bending at the n-Si surface leads to the generation of an electric field, which provides an energy barrier for the holes (minority) at the interface and reduces the carrier recombination with the electrons (majority carriers). Also, the band bending produces field-effect passivation by creating 
an imbalance in charge carrier (electron/hole) concentration due to the repulsion of holes at $\mathrm{LiF}_{\mathrm{x}} / \mathrm{Al}$ interface by enhnacing the minority carrier diffusion length within the bulk $\mathrm{n}-\mathrm{Si}$, which also led an increase in $\mathrm{J}_{\mathrm{sc}}$ of $\sim 3 \mathrm{~mA} / \mathrm{cm}^{2}$ from the cell [15]. An increment in $\mathrm{V}_{\mathrm{oc}}(\sim 20 \mathrm{mV})$ is observed due to the large minority carrier density with the better quasi fermi-level splitting. However, in our experimental results, an improvement of $\sim 25 \mathrm{mV}$ in $\mathrm{V}_{\text {oc }}$ is observed [15], the deviation from the experimental value can be because of other layers, which are not well calibrated. Also, a minor shunting effect due to the cell area is noted in the experimental $\mathrm{J}-\mathrm{V}$ graphs, which is not considered in the numerical simulation. The $\mathrm{LiF}_{\mathrm{x}}$ interface also reduces the fermi-level pinning at the c-Si surface, which is the case with the direct contact of Al with the n-Si wafer [18]. The thin $\mathrm{LiF}_{\mathrm{x}}$ interlayer capped with $\mathrm{Al}$ contact can also reduce the contact resistivity to some extent [19].

The collection of electrons happens from the rear side through carrier tunnelling, which is very sensitive to layer thickness [6]. Figures $3 \mathrm{a}$ and $3 \mathrm{~b}$ show the $\mathrm{J}-\mathrm{V}$ curves of cell and band diagrams of c-Si/LiF $/ \mathrm{Al}$ structure for different $\mathrm{LiF}_{\mathrm{X}}$ layers' thicknesses. The width of the tunnel barrier for charge carriers is very sensitive to $\mathrm{LiF}_{\mathrm{X}}$ thickness, which increases with an increase of $\mathrm{LiF}_{\mathrm{X}}$ thickness (from 1 to $2.5 \mathrm{~nm}$ ) and can be seen from figure $3 b$. For $\mathrm{LiF}_{\mathrm{x}}$ thickness $<2.5 \mathrm{~nm}$, the J-V curve does not show any change in its characteristics. However, a distortion in the shape of $\mathrm{J}-\mathrm{V}$ characteristic is observed for $\mathrm{LiF}_{\mathrm{x}}$ thickness $\geq 2.5 \mathrm{~nm}$ due to an increase of resistance to electrons from the cell's back side. The J-V curve deviates from its original characteristics shape, indicating an increase in series resistance, which lowers the cell's FF by $8 \%$ and efficiency by $\sim 2 \%$. The $n-S i$ conduction band bending also reduces with an increase in $\mathrm{LiF}_{\mathrm{X}}$ thickness due to an accumulation of electrons at the rear interface.

\subsection{Effect of $\mathrm{SiO}_{\mathrm{x}}$ front contact surface passivation on cell performance:}

Figures $4 \mathrm{a}$ and $4 \mathrm{~b}$ show the light $\mathrm{J}-\mathrm{V}$ graphs and energy band diagrams of the cells without and with $\mathrm{SiO}_{\mathrm{x}}$ interlayer at the front contact. The cell with $\mathrm{SiO}_{\mathrm{x}}$ interlayer shows an increase in efficiency by $\sim 2 \%$ as result of improvement in $\mathrm{V}_{\text {oc }}$ and $\mathrm{Jsc}$ by $\sim 57 \mathrm{mV}$ and $\sim 0.83 \mathrm{~mA}$, respectively. A difference in quasi hole fermi-level splitting is also observed for the cells.

An upward band bending results at the $\mathrm{MoO}_{\mathrm{x}} / \mathrm{c}$-Si interface due to carrier inversion at the c-Si surface because of the significant difference in WF between $\mathrm{MoO}_{\mathrm{x}}$ and $\mathrm{c}-\mathrm{Si}$, which is further enhanced with the $\mathrm{SiO}_{\mathrm{x}}$ interlayer. The upward bending enhances the holes collection and simultaneously provides an electron blocking field (due to carrier inversion) at the front contact. The enhanced field with the $\mathrm{SiO}_{\mathrm{x}}$ interlayer lowers the flow of electrons to the front contact and therefore reduces the charge carrier recombination with the better chemical passivation on the front c-Si surface. The recombination of carriers is proportional to the accessibility of both the charge carriers (electrons and holes) [20]. Thus, the $\mathrm{SiO}_{\mathrm{x}}$ interlayer accompanied by the $\mathrm{MoO}_{\mathrm{x}}$ hole-selective layer shows better performance due to the combined chemical and field-effect passivation. This effect has led to an enhancement of the $V_{\text {oc }}$ from $575 \mathrm{mV}$ to $632 \mathrm{mV}$ in the cell. Due to the insulating nature of $\mathrm{SiO}_{\mathrm{x}}$, a spike in the band diagram is noted at 
the $\mathrm{MoO}_{\mathrm{x}} / \mathrm{c}$-Si interface (Fig. 4b), which will allow the hole and can hinder the electron transport [21]. The thickness of $\mathrm{SiO}_{\mathrm{x}}$ should not be greater than the tunnel barrier limit $(\sim 2 \mathrm{~nm})$, so that the carriers can tunnel (band to band or hopping through traps) the interfacial barrier [22]. Also, the $\mathrm{SiO}_{\mathrm{x}}$ interlayer's uniformity is very important for achieving the uniform chemical passivation of c-Si surface by suppressing most of the silicon dangling bonds.

\subsection{Effect of $\mathrm{MoO}_{\mathrm{x}}$ work function on front contact of cell performance:}

To investigate the role of $\mathrm{MoO}_{\mathrm{x}}$ layer's WF, the device is simulated for a range of varying WF (from 4.80 to $6.70 \mathrm{eV}$ ). The simulated J-V graphs of cells and energy band diagrams of the $\mathrm{MoO}_{\mathrm{x}} / \mathrm{n}-\mathrm{Si}$ junction with different $\mathrm{MoO}_{\mathrm{x}} \mathrm{WF}$ are shown in figures $5 \mathrm{a}$ and $5 \mathrm{~b}$, respectively. The corresponding photovoltaic parameters are presented in table 2 . The $\mathrm{MoO}_{\mathrm{x}} / \mathrm{c}-\mathrm{Si}$ junction is taken as the Schottky contact due to a significant WF difference between the $\mathrm{MoO}_{\mathrm{x}}$ and $\mathrm{n}$-Si, which gives rise to upward band bending in the energy bandgap on the front c-Si surface [3].

Table 2 Photovoltaic parameters of cells obtained from simulations with different $\mathrm{MoO}_{\mathrm{x}}$ layer work functions.

\begin{tabular}{|lllll|}
\hline Work function $(\mathrm{eV})$ & $\mathrm{V}_{\mathrm{oc}}(\mathrm{mV})$ & $\mathrm{J}_{\mathrm{sc}}\left(\mathrm{mA} / \mathrm{cm}^{2}\right)$ & $\mathrm{FF}(\%)$ & Efficiency (\%) \\
\hline 4.8 & 454.20 & 32.47 & 63.50 & 9.36 \\
\hline 4.9 & 549.10 & 32.47 & 69.30 & 12.36 \\
\hline 5.0 & 577.80 & 33.78 & 79.06 & 14.84 \\
\hline 5.5 & 577.70 & 33.78 & 81.79 & 15.35 \\
\hline 6.0 & 602.30 & 35.24 & 81.53 & 17.47 \\
\hline 6.7 & 633.80 & 35.24 & 81.33 & 18.17 \\
\hline
\end{tabular}

With decreasing of $\mathrm{MoO}_{\mathrm{x}}$ layer's WF, the reduction in band bending is observed (Fig. 5b). The low band bending cannot produce a significant field to block the electrons and thus promotes the carrier recombination at the $\mathrm{MoO}_{\mathrm{x}} / \mathrm{c}-\mathrm{Si}$ interface with the photogenerated minority carrier (holes) [9]. Also, the low band bending hinders holes transport and increase the device resistance. However, in the case of higher $\mathrm{MoO}_{x} \mathrm{WF}(>6 \mathrm{eV})$, the carrier transport at the $\mathrm{MoO}_{\mathrm{x}} / \mathrm{c}-\mathrm{Si}$ interface happens through band-to-band tunnelling $[10,11]$. Also, a large hole concentration is induced at the interface, which inverts the charges' polarity at the c-Si surface. As a result, the hole conductivity is increased that provides better selectivity and leading to high $\mathrm{V}_{\mathrm{oc}}$. The decrease in $\mathrm{MoO}_{\mathrm{x}}$ layer's $\mathrm{WF}$ is observed due to the reduction of oxygen vacancies [23]. For the mid-range of $\mathrm{MoO}_{x} \mathrm{WF}(5.0 \mathrm{eV}<\mathrm{WF}<6.0 \mathrm{eV})$, the carrier transport happens through trap states that exist in the $\mathrm{MoO}_{\mathrm{x}}$ bandgap [12], which also can provide the low resistive path to electronic transportation. However, with the low value of $\mathrm{MoO}_{\mathrm{x}}$ layer's WF $<5.0 \mathrm{eV}$, a hole transport barrier is 
observed, which hinder the hole selectivity by $\mathrm{MoO}_{\mathrm{x}}$ layer and produce an S-shape in $\mathrm{J}-\mathrm{V}$ curves, which degrades the performance of the CSC solar cells [24].

Further improvement in the device efficiency can be visualised by employing high quality c-Si wafer. Figure 6 shows the simulated J-V curves under illumination with different c-Si bulk lifetimes, an enhancement in $V_{o c}$ is very clear with an improvement in the bulk lifetime of $n$-Si wafer from 300 to 1500 $\mu \mathrm{s}$. As a result, the device power conversion efficiency reaches $\sim 20 \%$ with $\mathrm{V}_{\text {oc }}$ of $>700 \mathrm{mV}$. So, the overall performance of the CSC solar cells can be fine tuned by good bulk lifetime values as well as with the better c-Si surface passivation quality.

\section{Conclusions}

For $\mathrm{Ag} / \mathrm{ITO} / \mathrm{MoO}_{\mathrm{x}} / \mathrm{n}-\mathrm{Si} / \mathrm{LiF}_{\mathrm{x}} / \mathrm{Al} \mathrm{CSC}$ solar cell, the $\mathrm{LiF}_{\mathrm{x}}$ interlayer is verified as an efficient electronselective layer compared to direct Al contact on the c-Si back contact. LiF $/$ /Al back contact's field effect is observed with downward band bending in simulated band diagram, which is reflected on the better performance of CSC cells. The carrier tunnelling length is limited by $\sim 2 \mathrm{~nm} \mathrm{LiF}$ layer, further increase in thickness is reduced field-effect passivation with the minimal conduction band bending. The improvement in CSC cells' performance has also been observed with a thin $\mathrm{SiO}_{\mathrm{x}}$ interlayer due to a significant reduction of surface recombination. The role of hole-selective front contact in carrier recombination and transport mechanisms is analysed by varying $\mathrm{MoO}_{x}$ 's work function in three different ranges (high, medium, and low). The hole collection barrier is observed with the low the work function of $\mathrm{MoO}_{\mathrm{x}}$ layer $(<5.0 \mathrm{eV})$. These numerical simulations can provide some information on the electronic properties of carrier-selective layers apart from the critical role fom surface passivation and bulk lifetime of base silicon wafer.

\section{Declarations}

\section{Acknowledgements}

Authors would like to acknowledge DST/Intel®/IUSSTF (Grant number: RP03472) for financial support of the research work, and Dr S. P. Singh for the fruitful discussion.

\section{Data Availability}

The datasets generated during and/or analysed during the current study are available from the corresponding author on reasonable request.

\section{References}

[1] J. Bullock, A. Cuevas, T. Allen, C. Battaglia, Molybdenum oxide MoOx: A versatile hole contact for silicon solar cells, Applied Physics Letters 105 (2014) 232109. 
[2] J. Dréon, Q. Jeangros, J. Cattin, J. Haschke, L. Antognini, C. Ballif, M. Boccard, 23.5\%-Efficient Silicon Heterojunction Silicon Solar Cell Using Molybdenum Oxide As Hole-Selective Contact, Nano Energy. 70 (2020) 104495.

[3] L.G. Gerling, S. Mahato, A. Morales-Vilches, G. Masmitja, P. Ortega, C. Voz, R. Alcubilla, J. Puigdollers, Transition metal oxides as hole-selective contacts in silicon heterojunctions solar cells, Solar Energy Materials and Solar Cells. 145 (2016) 109-115.

[4] J. Werner, J. Geissbühler, A. Dabirian, S. Nicolay, M. Morales-Masis, S. De Wolf, B. Niesen, C. Ballif, Parasitic Absorption Reduction in Metal Oxide-Based Transparent Electrodes: Application in Perovskite Solar Cells, ACS Applied Materials and Interfaces. 8 (2016) 17260-17267.

[5] M. Bivour, J. Temmler, H. Steinkemper, M. Hermle, Molybdenum and tungsten oxide: High work function wide band gap contact materials for hole selective contacts of silicon solar cells, Solar Energy Materials and Solar Cells. 142 (2015) 34-41.

[6] J. Bullock, P. Zheng, Q. Jeangros, M. Tosun, M. Hettick, C.M. Sutter-Fella, Y. Wan, T. Allen, D. Yan, D. Macdonald, S. De Wolf, A. Hessler-Wyser, A. Cuevas, A. Javey, Lithium Fluoride Based Electron Contacts for High Efficiency n-Type Crystalline Silicon Solar Cells, Advanced Energy Materials 6 (2016) 1-7.

[7] Y. Wan, C. Samundsett, J. Bullock, T. Allen, M. Hettick, D. Yan, P. Zheng, X. Zhang, J. Cui, J. McKeon, A. Javey, A. Cuevas, Magnesium Fluoride Electron-Selective Contacts for Crystalline Silicon Solar Cells, ACS Applied Materials and Interfaces. 8 (2016) 14671-14677.

[8] J. Cho, J. Melskens, M. Debucquoy, M. Recamán Payo, S. Jambaldinni, T. Bearda, I. Gordon, J. Szlufcik, W.M.M. Kessels, J. Poortmans, Passivating electron-selective contacts for silicon solar cells based on an a-Si:H/TiOx stack and a low work function metal, Progress in Photovoltaics Research and Applications 26 (2018) 835-845.

[9] S. Bhatia, A. Antony, P.R. Nair, Unraveling the Hole-Selective Nature of Si/MoOX Heterojunction, IEEE Journal of Photovoltaics. 10 (2020) 1566-1573.

[10] R.A. Vijayan, S. Masilamani, S. Kailasam, K. Shivam, B. Deenadhayalan, M. Varadharajaperumal, Study of Surface Passivation and Charge Transport Barriers in DASH Solar Cell, IEEE Journal of Photovoltaics. 9 (2019) 1208-1216.

[11] C. Messmer, M. Bivour, J. Schon, S.W. Glunz, M. Hermle, Numerical Simulation of Silicon Heterojunction Solar Cells Featuring Metal Oxides as Carrier-Selective Contacts, IEEE Journal of Photovoltaics. 8 (2018) 456-464.

[12] R.A. Vijayan, S. Essig, S. De Wolf, B.G. Ramanathan, P. Loper, C. Ballif, M. Varadharajaperumal, HoleCollection Mechanism in Passivating Metal-Oxide Contacts on Si Solar Cells: Insights from Numerical Simulations, IEEE Journal of Photovoltaics. 8 (2018) 473-482. 
[13] M. Nayak, S. Mandal, A. Pandey, S. Mudgal, S. Singh, V.K. Komarala, Nickel Oxide Hole-Selective Heterocontact for Silicon Solar Cells: Role of SiOx Interlayer on Device Performance, Solar RRL. 3 (2019) 1900261.

[14] S.W. Glunz, F. Feldmann, SiO2 surface passivation layers - a key technology for silicon solar cells, Solar Energy Materials and Solar Cells. 185 (2018) 260-269.

[15] M. Nayak, S. Mudgal, S. Singh, V.K. Komarala, Investigation of anomalous behaviour in J-V and SunsVoc characteristics of carrier-selective contact silicon solar cells, Solar Energy. 201 (2020) 307-313.

[16] Sentaurus Device User Manual Version N-2017.09, Synopsys, Mountain View, CA, USA, 2017. http://www.synopsys.com.

[17] PV Lighthouse, https://www.pvlighthouse.com.au/ (accessed March 9, 2021).

[18] J. Robertson, Band offsets, Schottky barrier heights, and their effects on electronic devices, Journal of Vacuum Science \& Technology A: Vacuum, Surfaces, and Films. 31 (2013) 050821.

[19] J. Bullock, M. Hettick, J. Geissbühler, A.J. Ong, T. Allen, C.M. Sutter-Fella, T. Chen, H. Ota, E.W. Schaler, S. De Wolf, C. Ballif, A. Cuevas, A. Javey, Efficient silicon solar cells with dopant-free asymmetric heterocontacts, Nature Energy. 1 (2016) 15031.

[20] K. Singh, M. Nayak, S. Singh, V.K. Komarala, Investigation of silicon surface passivation by sputtered amorphous silicon and thermally evaporated molybdenum oxide films using temperature- And injectiondependent lifetime spectroscopy, Semiconductor Science and Technology. 35 (2020) 125017.

[21] L.G. Gerling, C. Voz, R. Alcubilla, J. Puigdollers, Origin of passivation in hole-selective transition metal oxides for crystalline silicon heterojunction solar cells, Journal of Materials Research. 32 (2017) 260268.

[22] L.G. Gerling, G. Masmitja, P. Ortega, C. Voz, R. Alcubilla, J. Puigdollers, Passivating/hole-selective contacts based on V205/SiOx stacks deposited at ambient temperature, Energy Procedia, 124 (2017) 584-592.

[23] M.T. Greiner, L. Chai, M.G. Helander, W.M. Tang, Z.H. Lu, Metal/metal-oxide interfaces: How metal contacts affect the work function and band structure of MoO3, Advanced Functional Materials. 23 (2013) 215-226.

[24] K. Singh, M. Nayak, D. Kumar Singh, V.K. Komarala, Degradation study of carrier selective contact silicon solar cells with ageing: Role of silicon surface morphology, Solid-State Electronics. 179 (2021) 107987.

\section{Figures}


(a)

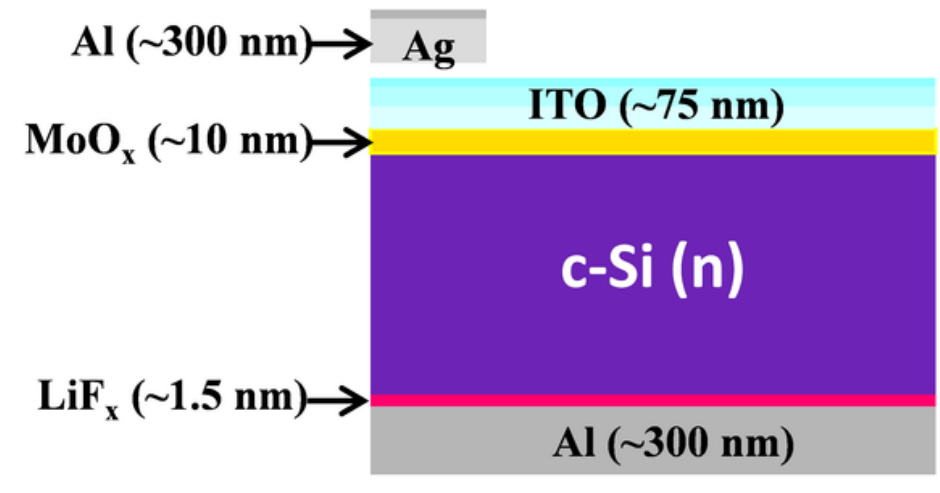

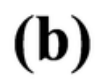

EF
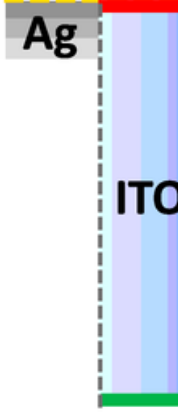

LiF $_{x}$ $E_{c}$ Al Ev

\section{Figure 1}

(a) Schematic, and (b) energy band diagram of simulated Ag/ITO/MoOx/c-Si(n)/LiFx/Al carrier-selective contact solar cell.
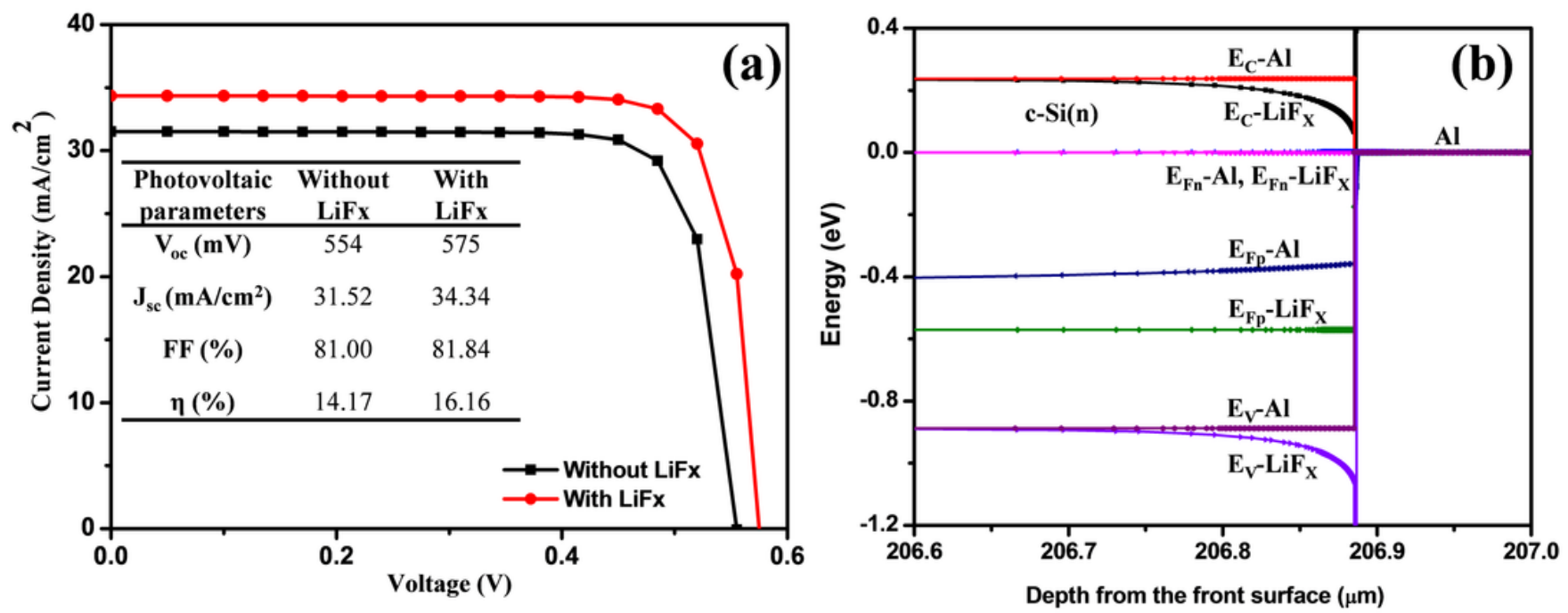

Figure 2

Simulated (a) light J-V graphs of cells, and (b) energy band diagrams of c-Si/Al interface with and without LiFx electron selective layer. Inset of the table in Fig. 2a shows the cells' photovoltaic parameters, EFn and EFp represent the electron and hole quasi fermi-levels in the c-Si energy bandgap under illumination condition. 

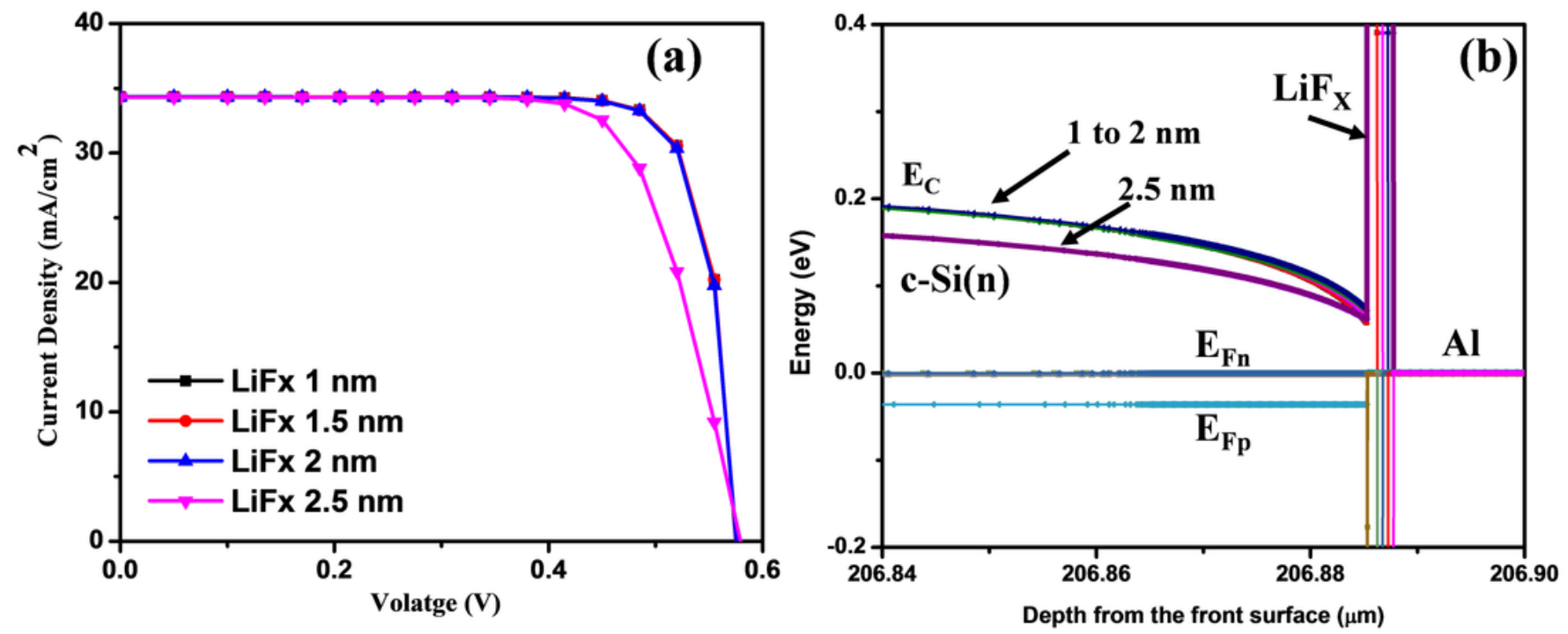

Figure 3

Simulated (a) light J-V curves, and (b) energy band diagrams of c-Si/LiFx/Al interface for different LiFx layer thickness, EFn and EFp in Fig. 3b represent the electron and hole quasi fermi-levels in the c-Si energy bandgap under illumination condition.
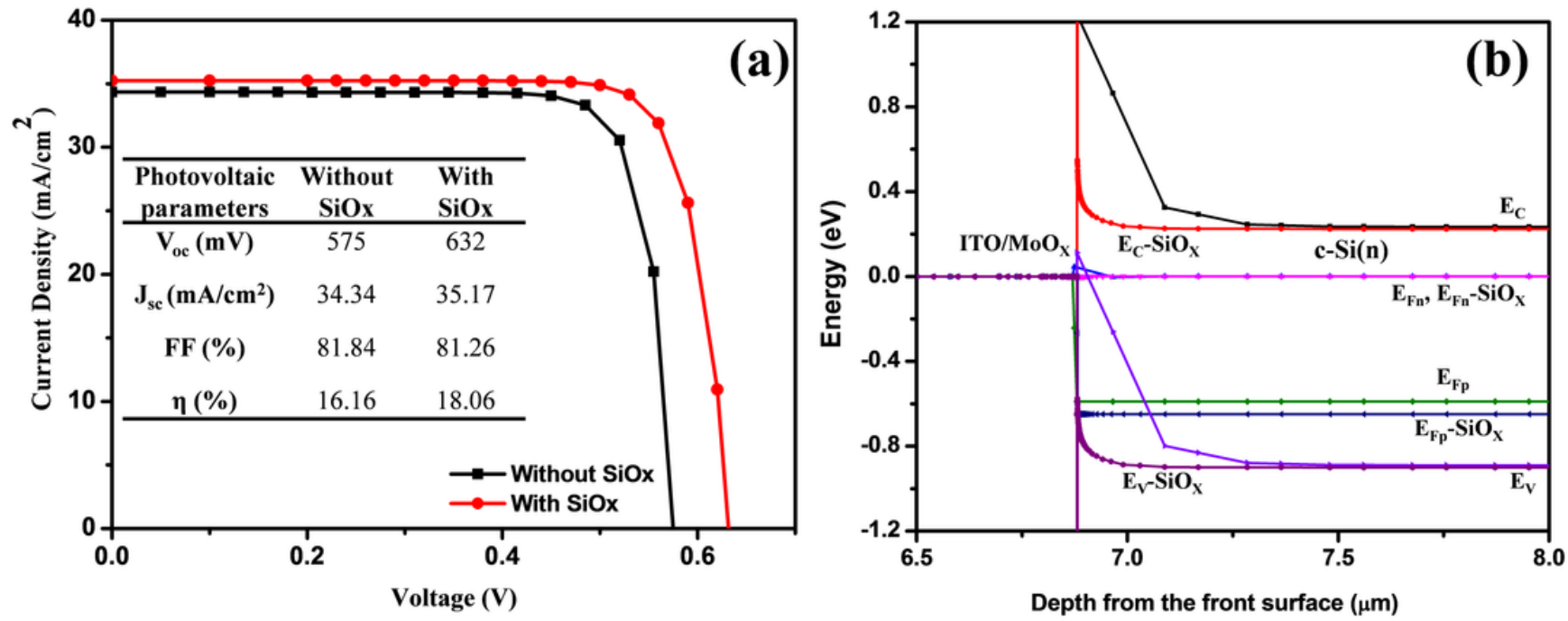

Figure 4

Simulated (a) light J-V curves and (b) energy band diagrams of front contact with and without SiOX passivation interlayer. Inset of the table in Fig. 4a shows the cells' photovoltaic parameters, EFn and EFp represent the electron and hole quasi fermi-levels in the c-Si energy bandgap under illumination condition. 

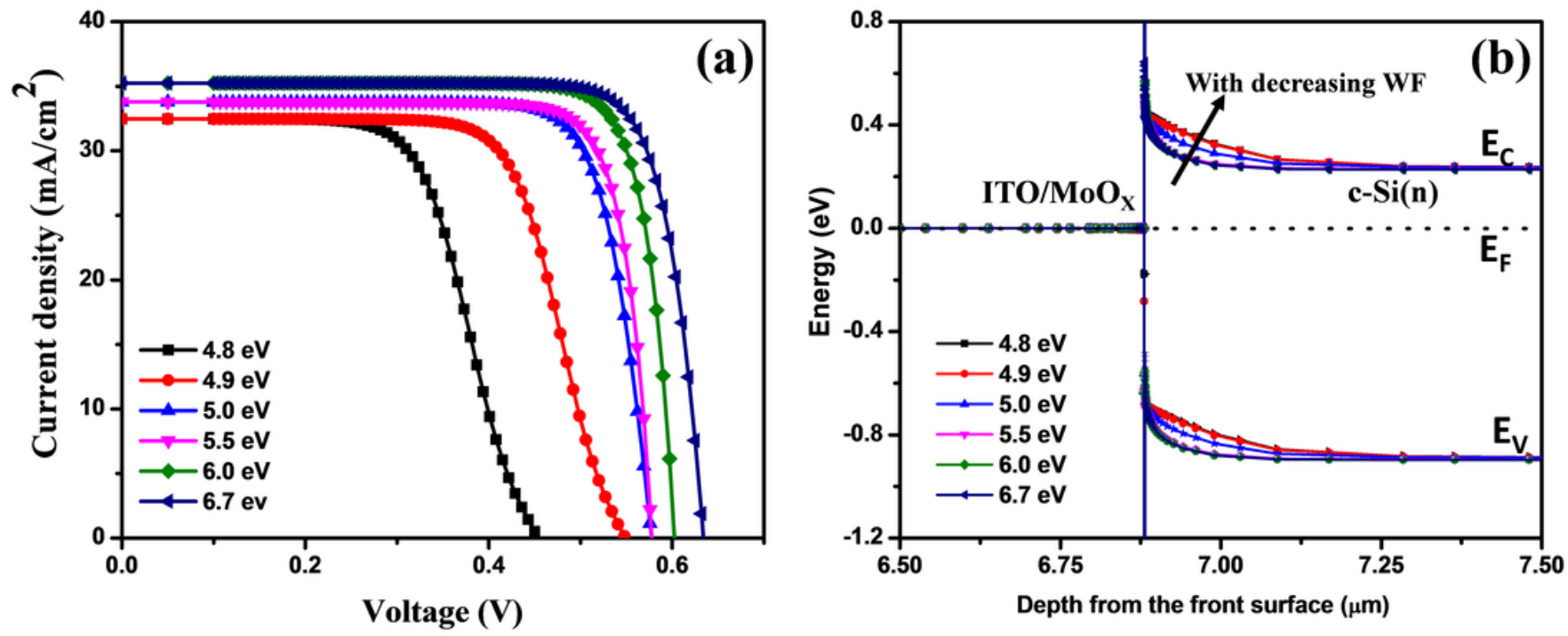

Figure 5

Simulated (a) light J-V graphs of cells and (b) energy band diagrams of MoOx/n-Si junction with the varying MoOx work function. 


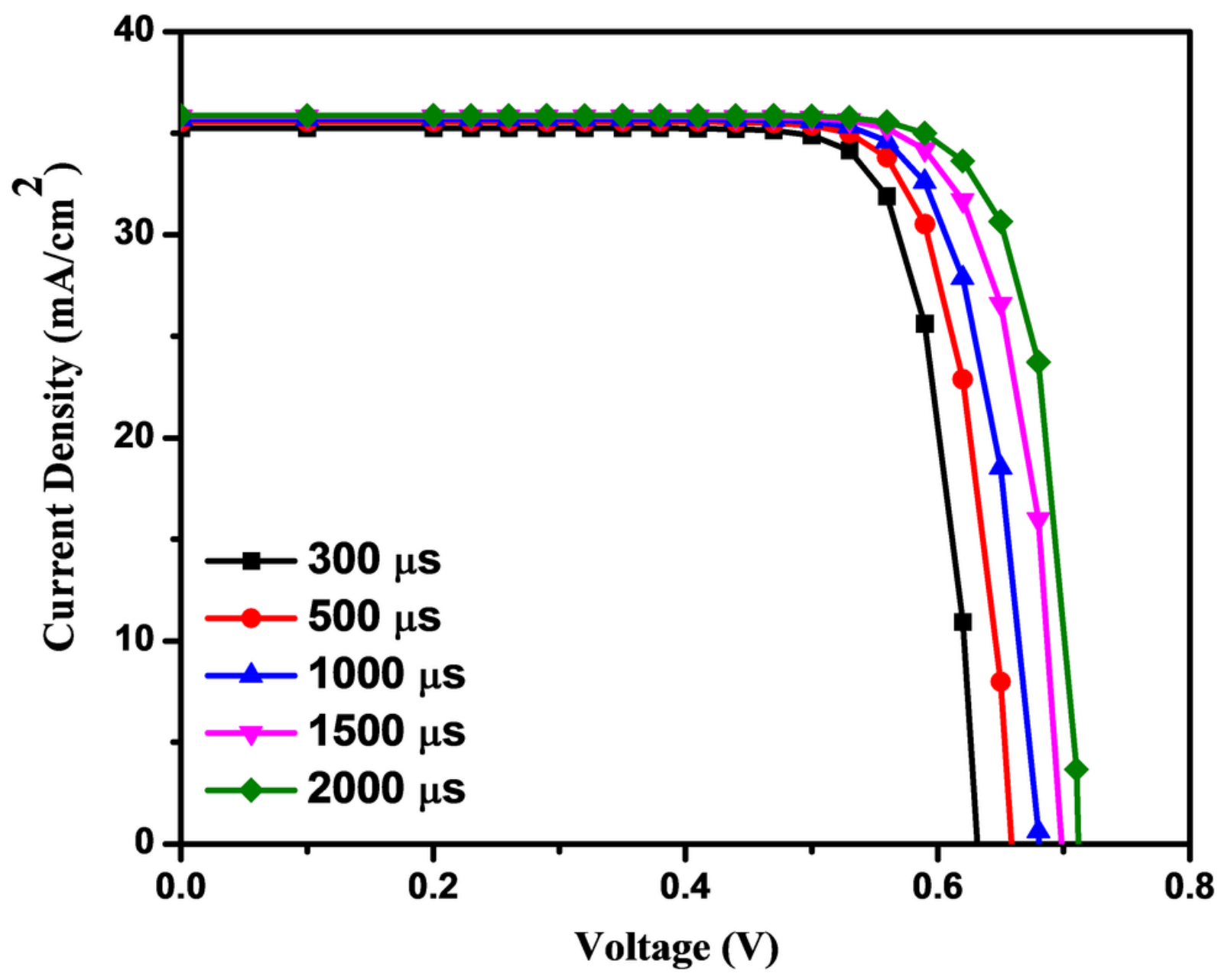

Figure 6

Simulated light J-V curves of CSC solar cells for different n-Si bulk lifetimes. 